\title{
UNAUTHORIZED PRACTICE OF LAW: SUPREME COURT HOLDS STATES CANNOT RESTRICT AUTHORIZED AGTIVITIES OF NONLAWYER PATENT OFFICE PRACTITIONER
}

STate efforts to restrict the rights of laymen practitioners before federal administrative agencies received a significant setback in the recent United States Supreme Court decision of Sperry v. Florida ex rel. Florida Bar. ${ }^{1}$ The Court ruled that the supremacy clause of the Constitution prevented the states from prohibiting a nonlawyer registered patent agent from engaging in activities authorized by the Commissioner of Patents.

Sperry, a registered practitioner before the United States Patent Office, but not a member of any state bar, was charged by the Florida Bar with engaging in the unauthorized practice of law in Florida." Admitting he had no right to practice law generally, Sperry answered in defense that he confined his work to proceedings involved in patent practice which were presented to or authorized by the Patent Office. However, relying on precedent ${ }^{3}$ and express constitutional power, ${ }^{4}$ the Florida Supreme Court held that Sperry's activities constituted unauthorized practice of law which the state could forbid, and that neither federal statutes nor the United States Constitution empowered any branch of the government to authorize such practice in Florida. The court thereupon issued a summary decree permanently enjoining Sperry from pursuing patent work in Florida, unless and until he became a member of the state bar. ${ }^{5}$

\footnotetext{
1373 U.S. 379 (1963) (Warren, C.J.) (unanimous decision).

2140 So. 2d 587 (Fla. 1962), rev'd, 373 U.S. 379 (1963), 17 U. MinMI L. Rev. 409 (1963), 14 W. REs. L. REv. 373 (1963).

${ }^{3}$ In Petition of Kearney, 63 So. 2d 630, 631 (Fla. 1953), the Florida Supreine Court had held that "those who hold themselves out to practice in any field or phase of law must be members of the Florida Bar...." Petitioner, licensed to practice before the United States Tax Court and the Treasury Department, sought, but was denied, permission to practice federal tax law in Florida.

The court also cited Chicago Bar Ass'n v. Kellogg, 338 Ill. App. 618, 88 N.E.2d 519 (1949); In re Baker, 8 N.J. 321, 85 A.2d 505 (1951); and West Virginia State Bar v. Earley, 144 W. Va. 504, 109 S.E.2d 420 (1959).

'FLA. CONST. art. V, $\$ 23$ (1956): "The supreme court shall have exclusive jurisdiction over the admission to the practice of law and the discipline of persons admitted ...." See also 31 FLA. STAT. ANN., Integration Rule of the Florida Bar, art. II, $\S 2$ (1956): "No person shall engage in any way in the practice of law in this state unless such person is an active member of The Florida Bar . . . ."

140 So. $2 d$ at 596. Sperry was enjoined from calling himself a patent attorner
} 
In reversing, the Supreme Court did not question Florida's determination that Sperry's activities consituted the practice of law in Florida. ${ }^{6}$ Furthermore, it did not doubt that Florida has a substantial interest in regulating the practice of law within the state which, in the absence of contrary federal legislation, could be exercised to prevent this circumscribed form of patent practice by nonlawyers. ${ }^{7}$ Instead the Court based its decision on the determination that all power as to patents has been delegated to Congress, ${ }^{8}$ that Congress has expressly authorized the Commissioner of Patents to permit practice before the Patent Office by nonlawyers, ${ }^{9}$ and that the Commissioner has explicitly exercised this delegated authority. ${ }^{10}$ The Court concluded that unless Congress had qualified its authorization, Florida was barred by the supremacy clause from imposing any additional requirements on persons who functioned within the scope of the federal license. ${ }^{11}$

The State of Florida contended that the federal authorization must be qualified by an implication that such practice should be

or holding himself out to be an attorney at law in Florida; from giving legal opinions, including opinions as to patentability or infringement on patent rights; from preparing, drafting, and construing legal documents; from preparing and prosecuting applications for letters patent and amendments thereto, or from holding himself out as qualified to do the same, while in Florida; and from engaging in the practice of law.

373 U.S. at 383. Citing Greenough v. Tax Assessors, 331 U.S. 486 (1947), and Murdock v. Memphis, 87 U.S. (20 Wall.) 590 (1874), the Court further noted that Patent Office work required the practitioner to advise his clients as to patentability, to draft the specifications and claims, and to prepare amendments in the application, when such are necessary.

7373 U.S. at 383 . See Konigsberg v. State Bar, 366 U.S. 36, 40-4I (1961); Schware v. Board of Bar Examiners, 353 U.S. 232, 239 (1957); Gardner v. Conway, 234 Minn. 468,48 N.W.2d 788 (195I).

${ }^{8}$ U.S. Const. art. I, § 8, cl. 8: "The Congress shall have Power . . To promote the Progress of Science and useful Arts, by securing for limited Times to Authors and Inventors the exclusive Right to their respective Writings and Discoveries."

- 35 U.S.C. § 31 (1958): "The Commissioner, subject to the approval of the Secretary of Commerce, may prescribe regulations governing the recognition and conduct of agents, attorneys, or other persons representing apphicants or other parties before the Patent Office, and may require them, before being recognized as representatives of applicants or other persons, to show that they are of good moral character and reputation and are possessed of the necessary qualifications to render to apphicants or other persons valuable service, advice, and assistance in the presentation or prosecution of their applications or other business before the office." (Emphasis added.)

1037 C.F.R. $\$ \S 1.31,1.341-.348(1960)$. In $\S 1.31$ the Commissioner declares, "An applicant for patent may file and prosecute his own case, or he may be represented by an attorney or agent authorized to practice before the Patent Office in patent cases." (Emphasis added.) Section 1.341(b) describes who may be an agent: "Any citizen of the United States not an attorney at law who fulfills the requirements and complies with the provisions of these rules may be admitted to practice before the Patent Office and have his name entered on the register of agents."

11373 U.S. at 385. See, e.g., Rice v. Santa Fe Elevator Corp., 331 U.S. 218 (1947). 
consistent with state law. ${ }^{12}$ However, after examining the legislative history and the development of the Patent Office rules and regulations, the Court held that Congress intended to give nonlawyer agents the right to practice before the Office whether or not the state would otherwise prohibit such conduct. ${ }^{13}$ Upon finding this intent, the Court decided that Congress had not exceeded the power necessary and proper to confer patent rights and that the legislative grant required the Patent Office to maintain standards high enough so as to avoid the criticism of improper delegation of congressional power to an administrative agency. ${ }^{14}$

Regulation of the practice of law in the public interest by the sovereign dates back to Roman Civilization. ${ }^{\mathbf{1 5}}$ In the United States, this duty has generally been assumed by the states as a part of their police power ${ }^{16}$ or as a power inherent in the judiciary. ${ }^{17}$ Important

13 Though the Florida brief was not available its arguments have been reconstructed from other sources. See vom Baur, Oral Argument in Florida State Bar $v$. Sperry, 29 U.P. NEws 20 (1963). Basically, Florida presented three arguments: (1) states have the right to control and regulate the practice of law; (2) statutory construction showed that Congress had never attempted to authorize nonlawyer practitioners to practice law relating to patents within the states, but only physically before the Patent Office; (3) if the statutes were construed to give nonlawyer practitioners the right to practice within the state, this would be unconstitutional as an invasion of the police powers of the state.

${ }^{28} 373$ U.S. at 388 . In summing up the legislative history, the Court stated: "Examination of the development of practice before the Patent Office and its governmental regulation reveals that: (1) nonlawyers have practiced before the Office from its inception, with the express approval of the Patent Office and to the knowledge of Congress; (2) during prolonged congressional study of unethical practices before the Patent Office, the right of nonlawyer agents to practice hefore the Office went unquestioned, and there was no suggestion that abuses might be curbed by state regulation; (3) despite protests of the bar, Congress in enacting the Administrative Procedure Act refused to limit the right to practice before the administrative agencies to lawyers; and (4) the Patent Office has defended the value of nonlawyer practitioners while taking steps to protect the interests which a State has in prohibiting unauthorized practice of law." The Court recoguized that "the authority of Congress is no less when the state power which it displaces would otherwise have been exercised by the state judiciary rather than by the state legislature." Id. at 403 .

14 See note 9 supra. In addition, 35 U.S.C. $\$ 32$ (1958) provides authority for suspending or dismissing agents for disreputable practice, gross misconduct, or failure to comply with the Patent Office rules, while 35 U.S.C. $\S 33$ (1958) sets a fine of up to $\$ 1,000$ for each offense where a person holds himself out to practice or who practices before the Patent Office without being an enrolled agent.

${ }^{25}$ vom Baur, Practice Before Administrative Agencies and the Unauthorized Practice of Law, 15 Fed. B.J. I03 (1955). See Pound, The Lawyer From ANTiQuity to Modern TIMES $5 I$ (1953).

${ }^{20}$ E.g., Chicago Bar Ass'n v. Kellogg, 338 Ill. App. 618, 88 N.E.2d 519 (1949); Clark v. Austin, 340 Mo. 467, 101 S.W.2d 977 (1937); Richmond Ass'n of Credit Men v. Bar Ass'n, 167 Va. 327, 189 S.E. 153 (1937).

${ }^{17}$ E.g., People ex rel. Chicago Bar Ass'n v. Goodman, 366 Ill. 346, 8 N.E.2d 941, cert. denied, 302 U.S. 728 (1937); In re Opinion of the Justices, 289 Mass. 607, 194 
policy reasons such as protecting the public from incompetent and unreliable advice, preserving and strengthening the lawyer-client relationship, and maintaining law as the foundation of government, necessitate restricting the practice of law. ${ }^{18}$ Although the courts have not been able to agree on a definition of practice of law, nonlawyers have been banned from activities ranging from the drawing of wills to claims-adjusting. ${ }^{10}$

Layman practice before governmental agencies is probably the area of greatest contention in the present day controversy over unauthorized practice of law. ${ }^{20}$ State courts have frequently enjoined authorized practice by nonlawyers before state agencies on the ground that such authorization is a legislative encroachment on the judicial domain. ${ }^{21}$ On the other hand, efforts to enjoin nonlawyer

N.E. 313 (1935); Clark v. Austin, 340 Mo. 467, 101 S.W.2d 977 (1937); West Virginia State Bar v. Earley, 144 W. Va. 504, 109 S.E.2d 420 (1959).

${ }^{18}$ E.g., West Virginia State Bar v. Earley, 144 W. Va. 504, 527, 109 S.E.2d 420, 435 (1959): "The justification for excluding from the practice of law persons who are not admitted to the bar ... is ... the protection of the public from being advised and represented in legal matters by unqualified and undisciplined persons over whom the judicial department of the government could exercise slight or no control."

See Adler, The Bar's Campaign Against Unauthorized Practice, 11 ARK. L. Rev. 320 (1957). See generally Otrerbourg, A Study of Unauthorized Practice of Law $1-26$ (1951); vom Baur, supra note 15.

Bar associations have in recent years taken the lcad in instituting unauthorized practice litigation. See Johnstone, The Unauthorized Practice Controversy, a Struggle Among Power Groups, 4 KAN. L. REv. 1 (1955). In 1938 there were approximately 430 bar association committces on unauthorized practice. Otterbourg, Collection Agency Activities: The Problem From the Standpoint of the Bar, 5 LAw \& CONTEMP. PROB. 35 (1938). Probably there are more such committees today. The American Bar Association has had an unauthorized practice committce since 1930 and publishes a quartcrly bulletin, Unauthorized Practice News.

The bar's activities have often causcd bad public rclations, because the public sees them merely as efforts to enforce a monopoly. Llewelleyn, The Bar's Troubles, and Poultices-and Cures?, 5 LAw \& Contemp. Prob. 104 (1938): “The problem of unauthorized practice of law is a problem of using the processes of the law to define and protect a monopoly." See also Johnstone, supra.

${ }^{10}$ E.g., People ex rel. Illinois State Bar Ass'n v. People's Stock Yards State Bank, 344 Ill. 462, 176 N.E. 901 (1931) (wills); Rhode Island Bar Ass'n v. Lesser, 68 R.I. 14, 26 A.2d 6 (1942) (claims-adjusting). See Annots., 111 A.L.R. 19 (1937); 125 A.L.R. 1173 (1940); 151 A.L.R. 781 (1944); and 33 Words ANd Phrasrs 193 (perm. ed. 1940), for a general survey as to what constitutes the practice of law.

${ }^{20}$ See Bennct, Non-Lawyers and the Practice of Law Before State and Federal Agencies, 46 A.B.A.J. 705 (1960); Robinson, Appeárances by Laymen in a Representative Capacity Before Administrative Bodies, 5 LAw \& ConTEMP. Prob. 89 (1938); The Practice of Non-Lawyers Before Administrative Agencies, 15 FED. B.J. 99-185, 211-36 (1955).

${ }^{21}$ People ex rel. Chicago Bar Ass'n v. Goodman, 366 Ill. 346, 8 N.E.2d 941 (1937) (Illinois Industrial Commission); West Virginia State Bar v. Earley, 144 W. Va. 504, 109 S.E.2d 420 (1959) (state Compensation Commission); State ex rel. State Bar v. 
practice before federal administrative agencies usually have been frustrated by the recognition and acceptance of the federal government's power to regulate its own agencies. ${ }^{22}$ However, the Florida court in Sperry ruled out such practice by nonlawyer patent practitioners, ${ }^{23}$ thus presenting a clear challenge to federal control of practice before its administrative agencies.

The Supreme Court's straightforward response to Florida's challenge offers scant opportunity for criticism. On the basis of statutory construction alone, supported by an analysis of the legislative history and the development of the Patent Office rules, the decision seems almost self-evident. Moreover, the decision is buttressed by several strong policy arguments.

One underlying consideration which strongly influenced the Court was fear of the disruptive effect which the decision below threatened to have upon Patent Office proceedings. ${ }^{24}$ This consideration has substantial merit. Had the Court upheld this decision, approximately half of the present Patent Office agents in the country would be disqualified. ${ }^{25}$ Replacing these practitioners would be extremely difficult since patent work is a specialized field which re-

Keller; 16 Wis.2d 377, 114 N.W.2d 796 (1962), rev'd on other grounds, 374 U.S. 102 (1963) (state Public Service Commission).

${ }^{22}$ Schroeder v. Wheeler, 126 Cal. App. 367, 14 P.2d 903 (1932) (Patent Office); Noble v. Hunt, 95 Ga. App. 804, 99 S.E.2d 345 (1957) (Treasury and Tax Court); Chicago Bar Ass'n v. Kellogg, 338 Ill. App. 618, 88 N.E.2d 519 (1949) (Patent Office); DePass v. B. Harris Wool Co., 346 Mo. 1038, 144 S.W.2d 146 (1940) (ICC); Auerbacher v. Wood, 139 N.J. Eq. 599, 604, 53 A.2d 800, 803 (1948) (NLRB); Application of New York County Lawyers Ass'n In re Bercu, 273 App. Div. 524, 534.35, 78 N.Y.S.2d 209, 218 (1948), aff'd, 299 N.Y. 728, 87 N.E.2d 45I (1949) (Treasury and Tax Court) (by implication); Sharp v. Mida's Research Bureau, Inc., 45 N.Y.S.2d 690 (1943), aff'd, 267 App. Div. 980, 48 N.Y.S.2d 799 (1944) (Patent Office); Battelle Memorial Institute v. Green, 133 U.S.P.Q. 49 (Ohio Ct. App. 1962) (Patent Office).

${ }^{28}$ See note 5 supra. Cf. Chicago Bar Ass'n v. Kellogg, 318 Ill. App. 618, 88 N.E.2d 519 (1949) (patent agent enjoined). For other cases restricting patent agents sce People ex rel. Colorado Bar Ass'n v. Erbaugh, 42 Colo. 480, 94 Pac. 349 (1908); Application of Plantamura, 22 Conn. Supp. 213, 166 A.2d 859 (1960), aff'd, 149 Conn. 1Il, 176 A.2d 61 (1961), cert. denied, 369 U.S. 872 (1962); Marshall v. New Inventor's Club, Inc., 117 N.E.2d 737 (Ohio G.P. 1953). Contra, Schxoeder v. Wheeler, 126 Cal. App. 367, 14 P.2d 903 (1932); Battelle Memorial Institute v. Green, 133 U.S.P.Q. 49 (Ohio Ct. App. 1962); cf. Zenith Radio Corp. v. Radio Corp. of America, 121 F. Supp. 792 (D. Del. 1954); Sharp v. Mida's Research Bureau, Inc., 45 N.Y.S.2d 690 (1943), aff'd, 267 App. Div. 980, 48 N.Y.S.2d 799 (1944).

24373 U.S. at $401-02$.

${ }^{25}$ The Government in an amicus curiae brief noted that, as of November, 1962, of the 7,544 persons registered to practice before the Patent Office, 1,801 were not lawyers, and 1,687 others were not lawyers admitted to the bar of the state in which they were practicing. Brief for the United States as Amicus Curiae, p. 3. Sixty-two of seventy-three patent practitioners in Florida were not members of the Florida Bar. 373 U.S. at 401 n.44. 
quires scientific and technical qualifications often not possessed by lawyers. ${ }^{26}$

Furthermore the Court did not believe there was any substance to Florida's concern that unskilled and unethical practitioners might victimize her citizens. ${ }^{27}$ The Florida Supreme Court had admitted in its opinion that its decision in no way was meant to imply that Sperry was unskilled, but only that he did not qualify under Florida's laws. ${ }^{28}$ It would seem clear that Florida's speculative fears are hardly sufficient reason to justify interference with federal patent agents in light of the rigid standards and safeguards provided by the Patent Office rules for regulating those who practice before it. ${ }^{20}$ Therefore, layman practice before the Patent Office would not unfairly prejudice the states in their efforts to effectuate the policy reasons justifying the restriction of the practice of law.

Peculiarly absent from the Sperry opinion was any real attempt by the Court to analyze the right of Congress or the Patent Office to decide who may practice before the agency. Although this was the very foundation on which Sperry's argument rested, the Court merely assumed that this right existed. ${ }^{30}$ It might have been contended that Congress and the federal agencies are invading a basically judicial area when they permit practice by nonlawyers, and hence, that the courts can prevent such practice. ${ }^{31}$ This conceptu-

${ }^{30}$ See United States v. Duell, 172 U.S. 576, 586 (1889). The investigation of patent claims "requires the intelligent judgment of a trained body of skilled officials, expert in the various branches of science and art...."

27373 U.S. at 402 .

${ }^{28} 140$ So. $2 \mathrm{~d}$ at 595 .

${ }^{20}$ Under 37 C.F.R. $\$ 1.341(\mathrm{c})$ (1960), any person seeking to practice before the Patent Office must establish "that he is of good moral character and of good repute and possessed of the legal and scientific and technical qualifications necessary to enable him to render applicants for patents valuable service, and is otherwise competent to advise and assist them in the preparation and prosecution of their applications before the Patent Office."

The Court noted that "failure to comply with these standards may result in suspension or disbarment. 35 U.S.C. $\$ 32$; 37 C.F.R. $§ 1.348$." 373 U.S. at 402. See Kingsland v. Dorsey, 338 U.S. 318 (1949) (disbarment of practitioner for misconduct). See generally Note, Admission to Practice Before and Disbarment From Federal Administrative Agencies, 12 SYRAcuse L. REv. 477 (1961).

${ }^{30} 373$ U.S. at 403 . See Goldsmith v. United States Bd. of Tax Appeals, 270 U.S. 117 (1926) (upholding right of an agency to prescribe procedure for admission of practitioners).

${ }^{81}$ This argument was suggested in a philosophical brief filed as amici curiae on behalf of the state bar associations. Florida did not adopt this position, and it was not presented in oral argument.

Perbaps, however, the Court alluded to it in passing: "We have not overlooked 
alistic argument, which is based on a strict separation of powers theory, has been used by many state courts in striking down legislatively or administratively conferred rights of nonlawyers to practice before agencies. ${ }^{32}$ The fundamental premise is that only lawyers may practice law, and attempts by any branch of the government to authorize nonlawyers to practice law may be invalidated by the courts through their inherent judicial power. According to this argument, the Supreme Court, having accepted Florida's determination that Sperry's activities constituted the practice of law, could have similarly drawn upon its inherent power to prevent the instant encroachment by the Patent Office into the judicial realm.

However, had Florida pressed this point, it is unlikely the Supreme Court would have reached a contrary decision. The same policy considerations-fear of disruption in Patent Office proceedings and the belief that adequate standards are enforced in that Office-which justified preventing Florida's interference with the Patent Office procedure would also apply to preclude such interference by the federal courts, even though nonlawyer patent practitioners might be considered to be practicing law. A few state courts have shown restraint by not invalidating state legislative authorizations permitting practice by nonlawyer agents unless there has been some harmful activity or abuse. ${ }^{33}$ Also, previous decisions of the Supreme Court upholding the authority of the Patent Office to determine the qualifications of those who appear before it indicate the Court's unwillingness to assert its judicial power unnecessarily into the basically legislative domain of federal agencies. ${ }^{34}$

Although Sperry was concerned only with practice before the Patent Office, perhaps the greatest significance of the case is the reasonable expectation that its rationale will be applied to other

respondent's constitutional arguments, but find them singularly without merit." 373 U.S. at 403. See Comment, Control of the Unauthorized Practice of Law: Scope of Inherent Judicial Power, 28 U. CHI. L. REv. 162 (1960). See generally Dowling, The Inherent Power of the Judiciary, 21 A.B.A.J. 635 (1935).

${ }^{82}$ See cases cited in notes 17 and 21 supra.

${ }^{38}$ See Birmingham Bar Ass'n v. Phillips \& Marsh, 239 Ala. 650, 196 So. 725 (1940); Bessemer Bar Ass'n v. Fitzpatrick, 239 Ala. 663, 196 So. 733 (1940); Cowern v. Nelson, 207 Minn. 642, 290 N.W. 795 (1940); Washington State Bar Ass'n v. Washington Ass'n of Realtors, 41 Wash.2d 697, 251 P.2d 619 (1952). See generally Comment, supra note 31 .

84 See United States v. Duell, 172 U.S. 576 (1899); Goldsmith v. United States Bd. of Tax Appeals, 270 U.S. 117 (1926); Gellhorn, Cincinnati Conference on Law and Lawyers in the Modern World, i5 U. Cinc. L. REv. 127, 196 (1941). 
federal agencies. In a case decided only two weeks after Sperry, ${ }^{35}$ the Supreme Court extended the holding in the instant case to practice before the Interstate Commerce Commission, which has rules and regulations similar to those of the Patent Office and requires practitioners trained in technical traffic and transportation skills as well as in law. ${ }^{36}$ But unlike the Patent Office, which specifically directs that most of its work be carried on by mail, ${ }^{37}$ the ICC conducts frequent hearings of an advocacy nature which under its rules are open to agents and attorneys alike. ${ }^{38}$ Advocacy is one area which lawyers have traditionally regarded as their own legitimate monopoly, and despite the Court's apparent acquiescence in advocacy by nonlawyers, this problem will probably remain a continuing source of friction.

Practice before the Treasury Department and the United States Tax Court present other friction areas in the field of unauthorized practice of law. Treasury Department and Tax Court rules allow non-attorneys a wide range of practice before them..$^{30}$ The Secretary of the Treasury issued an official interpretation of the departmental rules in 1956, directing that "all persons enrolled to practice before it [the Treasury Department] be permitted to fully represent their clients before it." 40 Despite this interpretation, the California Court

${ }^{35}$ Keller v. Wisconsin ex rel. State Bar, 374 U.S. 102 (1963), vacating and remanding per curiam 16 Wis.2d 377, 114 N.W.2d 796 (1962). Petitioner had been enjoined by the state from appearing as an advocate for others before public agencies, including the Interstate Commerce Commission.

${ }^{\text {so See }} 49$ C.F.R. $\$ \S$ 1.7-.13 (1962); Konigsberg, Examination of Non-Lawyers for Admission to Practice Before the Interstate Commerce Commission, 17 ICC PRACr. J. $503(1950)$.

37 See 37 C.F.R. \$ $1.2(1960)$.

${ }^{30}$ See 49 C.F.R. $\S 1.5(\mathrm{~b})$ (1962). See generally Singer, Practice of Non-Lawyers Before the Interstate Commerce Commission, 15 FED. B.J. 177 (1955).

${ }^{30}$ See 31 C.F.R. § 10 (1959) (Treasury Department); 26 C.F.R. $\S 701.2$ (1961) (Tax Court); Kilpatrick, Treasury Department Practice, 15 FED. B.J. 132 (1955); Phillips, Practice Before the Tax Court of the United States, 15 FED. B.J. 143 (1955); Comment, What Is the "Practice of Law?"-a Commentary on the Tax Practice Controversy, 36 U. DET. L.J. 464 (1959).

1021 Fed. Reg. 833 (1956). The purpose of the official interpretation was to make it clear that enrolled agents were to have the same rights and duties as an enrolled attorney. Carey, AIA's Carey Folds Treasury Interpretation Protects CPAs in Treasury Practice, 5 J. TAxation 42 (1956).

But see Clark, Treasury's Interpretation of Circular 230 Raises New Doubts on Practice by Accountants, 4 J. TAXamon 216 (1956); Correa, AIA's Council Sees No Difficulty With Treasury's Statement; Disagrees With Clark, 4 J. Taxamon 219 (1956); Clark, State Courts' Interest in Treasury Practice Cannot Be Ignored-A Reply to Mr. Correa, 4 J. TAXation 306 (1956). 
of Appeals later the same year in Agran v. Shapiro ${ }^{41}$ held that enrollment before the Treasury Department did not authorize one to perform acts connected therewith which constituted the practice of law in California. Although a different agency was involved in Agran, the situation is closely analogous to Sperry, and it would seem likely that the Sperry holding would control to prevent such state interference.

Even though extension of Sperry to other federal agencies appears likely, it does not follow that, whenever activities involve federal subject matter, the states have no power to regulate them. The Pennsylvania Supreme Court has held that admittance to practice before a federal district court does not give a person the right to practice generally within the district without being a member of the state bar, even if the practice is limited to the federal courts. ${ }^{42}$ On appeal, the United States Supreme Court refused to interfere for want of a federal question, in contrast to its reaction in Sperry when restrictions were placed on federal agency practice. This is not an inconsistent result because, except for the District of Columbia, federal courts have customarily followed the requirements of states in admitting persons to practice before them. ${ }^{43}$ These federal courts have no procedure of their own for determining either the legal ability or moral character of their practitioners.44 Also, the compelling policy reasons of nation-wide uniformity of practice and the fear of disruption of settled and accepted procedures are not so involved in federal court practice as they are in the case of federal agency practice.

Generally Congress has made each agency responsible for policing its own ranks, a job the agency is probably best qualified to do. For this reason, at least in agencies where procedures and precau-

\footnotetext{
\$1 5 J. Taxatron 272 (App. Div. Super. Ct. 1956), affirming 127 Cal. App.2d 807, 273 P.2d 619 (1954), 68 HARv. L. REv. 376 (1954), 33 N.C.L. REv. 252 (1955), 30 N.Y.U.L. Rev. 492 (1955). But see Craue-Johnson Co. v. Commissioner, 105 F.2d 740 (8th Cir. 1939). See generally Clark, New Agran Decision Raises Constitutional Ques. tions; Confuses Rules of Tax Practice, 5 J. TAxation 271 (1956). Because the case was believed to fall short as a satisfactory base on which to adjudicate finally the position of certified public accountants in Treasury practice, no appeal was taken to the United States Supreme Court. Editorial, The Agran Case in Perspective, 102 J. Ac. COUNTANCY 29, 30-31 (Dec. 1956).

$\$ 2$ Ginsburg v. Kovrak, 392 Pa. 143, 139 A.2d 889, appeal dismissed per curiam, 358 U.S. 52 (1958), 72 HARv. L. REv. 580 (1959), 107 U. PA. L. REv. 404 (1959).

"See In re Isserman, 345 U.S. 286, 287 (1953). But see Theard v. United States, 354 U.S. $278(1957)$.

"See In re Dreier, 258 F.2d 68, 69 (3d Cir. 1958).
} 
tions similar to those of the Patent Office are followed, ${ }^{45}$ the Court will likely apply the supremacy clause to prevent state hindrance of federal agency practice. Otherwise a practitioner's rights would hinge on geography, and uniformity of practice before the agencies would be destroyed. When confronted by these powerful countervailing policy considerations, fine-spun definitions of the practice of law and abstract theorizing about inherent judicial power are inadequately adapted to the solution of many of the conflicts in the penumbra occupied by both lawyer and layman practitioners.

¿In addition to the Treasury Department (Internal Revenue), 23 Stat. 258 (1884), b U.S.C. $\$ 261$ (1958); 31 C.F.R. $\$ \S 10.1-.94$ (1959); the Interstate Commerce Commission, 54 Stat. 913 (1940), 49 U.S.C. $\$ 17$ (12) (1958); 49 C.F.R. $\$ \S 1.7-.13$ (1962); and the Patent Office, 35 U.S.C. $\$ \S 31-33$ (1958); 37 C.F.R. $\$ \S 1.341-.348$ (1960); those agencies most directly affected are the United States Tax Court, 68A Stat. 884 (1954), 26 U.S.C. $\$ 7453$ (1958); 26 C.F.R. $\$ 701.2$ (1961); the Federal Maritime Commission, 49 Stat. 1987 (1936), 46 U.S.C. $§ 1114(b)$ (1958); 46 C.F.R. $§ 201.26$ (1963); the General Accounting Office, 42 Stat. 25 (1921), 31 U.S.C. $\S 52$ (1958); 4 C.F.R. $\S \S$ 1.1-1.8 (1961); and the Veterans Administration, 49 Stat. 2031 (1936), 38 U.S.C. $\$ \S$ 3401-05 (1958); 38 C.F.R. $\$ \$ 14.626-.663$ (1957). 